\title{
The Economic Effect of the Fertilization of the Increment of the Production and on the Amelioration of the Quality of the Tobacco
}

Edmond Kadiu

Department of Rural Tourism Management, Agricultural University of Tirana

Majlinda Belegu

Department of Mathematics and Informatics, Agricultural University of Tirana majlindabelegu@yahoo.com

Mariana Nikolla

Department of Mathematics and Informatics, Agricultural University of Tirana

Orkida Totojani

Department of agribusiness management, Agricultural University of Tirana

Erdit Nesturi

Department of Economics and Agricultural Policy, Agricultural University of Tirana

Albina Basholli

Department of Mathematics and Informatics, Agricultural University of Tirana

Doi:10.5901/ajis.2013.v2n8p617

\section{Abstract}

Combination utilization of nitrogen- phosphates and potassium fertilization in the studied proportions has a direct impact on the production increment and in the amelioration of the quality of the tobaccos. Fertilization maintains a weight proportion between the carbohydrates and proteins, which should be $1.5-2$ favouring the carbohydrates. The best proportion is in the variant N40P60K40-60. Tobacco reacts toward soil fertility and the fertilization by assimilating nutrient elements, which are in them to complete its biological indispensable requirements. It has been determinate that $1 \mathrm{kv}$ tobacco product should assimilate $4.1 \mathrm{~kg}$ $\mathrm{N}, 1.6 \mathrm{~kg} \mathrm{P}$ and $7.0 \mathrm{~kg} \mathrm{~K}$. The augmentation of the production quality is very important in the tobacco cultivation because on this depends its use value, to be as much aromatic as possible, testily and as little as possible harmful for the consumer. In this study was proved the combination of doses of nitrogen, phosphate and potassium fertilization in each other's background, in determined proportion among them. The doses of nitrogen fertilization from $40 \mathrm{~kg} / \mathrm{ha}$ to $90 \mathrm{~kg} / \mathrm{ha}$ active nitrogen were studied in the background of $60 \mathrm{~kg} / \mathrm{ha}$ phosphor, $60 \mathrm{~kg} / \mathrm{ha}$ background of $40 \mathrm{~kg} / \mathrm{ha}$ active nitrogen and $60 \mathrm{~kg} / \mathrm{ha}$ active potassium; phosphor doses of $40-90 \mathrm{~kg} / \mathrm{ha}$ are also studied in details, while the effects of potassium fertilization was determinate in the background N40 P60kg/ha.

Keywords; Consumer benefit, product quality, direct impact, used value.

\section{Introduction}

In this paper we present a scientific way and on the basis of data processing, greater economic importance of tobacco production that represents and influence in our country. This matter arising as a result of great potential that we have to produce and to reduce the levels of imports and negative impact on the Albania economy, based in production and consumption of tobacco.

Combination utilization of nitrogen- phosphates and potassium fertilization in the studied proportions has a direct impact on the production increment and in the amelioration of the quality of the tobaccos. Fertilization maintains a weight 
proportion between the carbohydrates and proteins, which should be $1.5-2$ favouring the carbohydrates. The best proportion is in the variant N40P60K40-60.

\section{Material and Methods}

Tobacco reacts toward soil fertility and the fertilization by assimilating nutrient elements, which are in them to complete its biological indispensable requirements. It has been determinated that $1 \mathrm{kv}$ tobacco product should assimilate $4.1 \mathrm{~kg} \mathrm{~N}, 1.6$ $\mathrm{kg} \mathrm{P}$ and $7.0 \mathrm{~kg} \mathrm{~K}$. The augmentation of the production quality is very important in the tobacco cultivation because on this depends its use value, to be as much aromatic as possible, testily and as little as possible harmful for the consumer.

In this study was proved the combination of doses of nitrogen, phosphate and potassium fertilization in each other's background, in determined proportion among them. The doses of nitrogen fertilization from $40 \mathrm{~kg} / \mathrm{ha}$ to $90 \mathrm{~kg} / \mathrm{ha}$ active nitrogen were studied in the background of $60 \mathrm{~kg} / \mathrm{ha}$ phosphor, $60 \mathrm{~kg} / \mathrm{ha}$ background of $40 \mathrm{~kg} / \mathrm{ha}$ active nitrogen and $60 \mathrm{~kg} / \mathrm{ha}$ active potassium; phosphor doses of $40-90 \mathrm{~kg} / \mathrm{ha}$ are also studied in details, while the effects of potassium fertilization was determinate in the background N40 P60kg/ha.

\section{Results and Discussion}

The plant's measurements show that the effect of fertilization is different regarding the bio -metric endears as are plant's length, the leaf's number and their dimensions (Table 1). In the variant where $90 \mathrm{~kg} / \mathrm{ha}$ active nitrogen matters are used, plants are $55 \mathrm{~cm}$ longer then in control sample and $15-20 \mathrm{~cm}$ higher than in the variants when phosphor and potassium is used, while in variants without phosphate, plants are less grown. The combined nitrogen, phosphate and potassium fertilization directly influences the productivity and the amelioration of tobacco qualities (Table 2).

It is indispensable that for the production of high quality tobacco, the content of nicotine shouldn't be higher the 1 $25 \%$ and that of nitrogen shouldn't be higher $2-3 \%$. When the dose of phosphor and potassium was increased from 40 to $90 \mathrm{~kg} / \mathrm{ha}$, the content of carbohydrates was increased $8.1-9.3 \%$. The same trend is noticed regarding proteins, which are increased when the quality of nitrogen fertilization is increased from 5.3 to $6.7 \%$.

Table 1. Biometric indexes of plant.

\begin{tabular}{|c|c|c|c|c|c|}
\hline \multirow{2}{*}{ No } & Variants & $\begin{array}{c}\text { Highness } \\
\mathrm{cm}\end{array}$ & $\begin{array}{c}\text { Augmentation } \\
\text { Towards control } \\
\mathrm{cm}\end{array}$ & $\begin{array}{c}\text { Length } \\
\mathrm{cm}\end{array}$ & $\begin{array}{c}\text { Width } \\
\mathrm{cm}\end{array}$ \\
\cline { 3 - 6 } & 0 & 135 & - & 28 & 13 \\
\hline 1 & P60K60 & 150 & 15 & 29 & 14 \\
\hline 3 & P60K60N40 & 154 & 15 & 29 & 14 \\
\hline 4 & P60K60N60 & 160 & 25 & 32 & 16 \\
\hline 5 & P60K60N90 & 190 & 55 & 33 & 17 \\
\hline 6 & N40K60 & 162 & 27 & 30 & 14 \\
\hline 7 & N40K60P40 & 173 & 40 & 30 & 14 \\
\hline 8 & N40K60P90 & 150 & 15 & 31 & 15 \\
\hline 9 & N40P60 & 153 & 20 & 30 & 14 \\
\hline 10 & N40P60K40 & 154 & 19 & 30 & 14 \\
\hline 11 & N40P60K90 & 154 & 19 & 30 & 14 \\
\hline
\end{tabular}
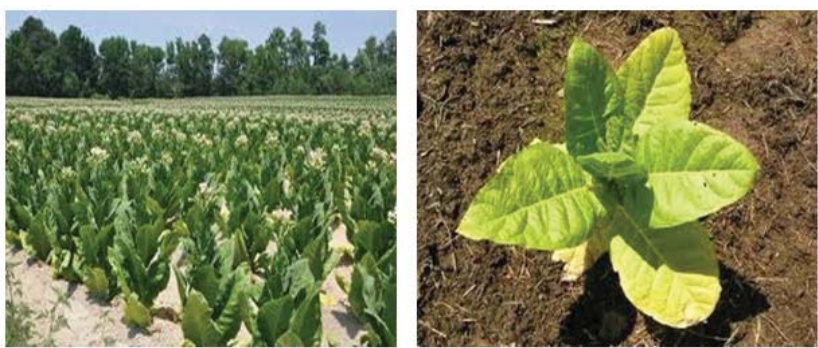

Figure 1. Tobacco plants by Albanian farms 
Table 2. Productivity and quality of tobacco

\begin{tabular}{|c|c|c|c|c|c|c|c|c|}
\hline \multirow{2}{*}{$\mathrm{Nr}$} & \multirow{3}{*}{ Variants } & \multicolumn{4}{|c|}{ Productivity } & \multicolumn{2}{c|}{$\begin{array}{c}\text { Augmentation } \\
\text { towards control }\end{array}$} & $\begin{array}{c}\text { Quality of } \\
\text { I- III class \% }\end{array}$ \\
\cline { 3 - 9 } & & 1985 & 1986 & 1987 & Average & Kv & $\%$ & $\%$ \\
\hline 1 & 0 & 10.2 & 9.9 & 7.9 & 8.3 & - & 100 & 100 \\
\hline 2 & P60K60 & 12.1 & 12.3 & 12.2 & 12.2 & 2.9 & 124.1 & 112 \\
\hline 3 & P60K60N40 & 16.7 & 16.4 & 15.1 & 16.2 & 6.8 & 173.1 & 115 \\
\hline 4 & P60K60N60 & 17.6 & 17.3 & 17.5 & 17.5 & 8.2 & 189.2 & 105 \\
\hline 5 & P60K60N90 & 19.6 & 19.4 & 19.2 & 19.4 & 10.1 & 208.6 & 102 \\
\hline 6 & N40K60 & 15.3 & 15.4 & 15.1 & 15.2 & 5.9 & 163.4 & 100 \\
\hline 7 & N40K60P40 & 16.4 & 16.3 & 15.4 & 16.1 & 8.8 & 173.1 & 108 \\
\hline 8 & N40K60P90 & 18.2 & 17.7 & 16.9 & 17.1 & 7.8 & 184.0 & 110 \\
\hline 9 & N40P60 & 17.2 & 17.6 & 17.1 & 17.3 & 8.0 & 186.0 & 97 \\
\hline 10 & N40P60K40 & 17.5 & 17.8 & 17.6 & 17.6 & 8.3 & 189.2 & 110 \\
\hline 11 & N40P60K90 & 18.3 & 18.0 & 17.8 & 18.0 & 8.7 & 193.7 & 117 \\
\hline
\end{tabular}

According to the analyses of variable, tobacco production and quality indicator shows that the average yield (for 3 years) is: $\mathrm{DMV}=0,01-2,3$.

\section{Production and Marketing of Tobacco in Albania}

Based on the important results of the case study that which suggest great economic importance of tobacco production in the country we find very important to make an analysis of the production of tobacco in the last 20 years.

Since 1991, the market of tobacco today is very different. At that time there were only a distribution company. While other brands of cigarettes supplied by different vendors. Then, begins to rise as the domestic industry producing cigarettes "English Tobacco", which started its operations in 1994 with a production capacity of 1000 tons. But this factory production gradually decreased until it closed its doors in anticipation of a foreign investor.

The same fate also suffered Cigarette Tobacco Factory in Durres, which has dozens of years of tradition, the first years '44. She has been leading cigarette factory in Bangladesh.

Almost all state factories came from year to year and consumption is declining gradually replaced by imports, although in Albania as factories, as well as tobacco. About 50000 families working in tobacco cultivation in hilly and mountainous areas that have had little income. Only tobacco industry employed 5,000 people and produced until '91 25000 tons of cigarettes per year. Our country at that time cigarettes consumed about 5,000 which and 20000 tonnes were exported mainly to other Eastern countries, not excluding the West with an amount several thousand tons.

Until 1999 it was the differential excise domestic production and import it, and reflect the percentage of the market value had cigarette packages. Until this year, Customs has been over $40 \%$ for imported cigarettes except excise was very high, $40 \%$ of the value, which was and some protection of domestic production. Other states still have to this day still very high.

In some countries over $50 \%$ duty paid, so the countries of the region. While we had a decrease in excise and customs duty because Customs was from $40 \%$ to $10 \%$, the same as the food products, excise and became the 7 and 11 ALL per pack, where the first category was the second quality and 11 all was the first quality.

However the difference is very small. At that time, only as a result of fiscal policies of cigarettes compete in the market place at least in the poor citizens seeking cheap cigarettes. But during this time, these barriers were removed. A customs fee so low for large factories such as Philip Morris, etc.., which are multinational manufacturer and have the best quality, the $10 \%$ no problem. Also excise on cigarettes as Marlboro or Dunhill was $11 \mathrm{ALL}$ and ALL 7 for most other cigarettes. Thus, almost leveled cigarettes country they import. Since this moment the country began cigarettes felt tremendous import competition.

There were large differences in market prices do not exist. Until 1999 Excise and occupied 135\% of the cigarette package that came from imports. In this year he became the reduction of excise and customs duties, this burden does not take more than $40-50 \%$ of the value and of course it is in favor of imports. So the market was oriented towards the latter. Actually consumed only imported cigarettes. While growing tobacco is only for export. Albanian Tobacco collected from two Greek companies abroad in order to recover.

Tobacco distributors have been greatly concerned because of the great sensitivity to customer input inscription in 
Albanian. Almost all companies have had a decrease in the number of customers at the time of cigarette packs wrote "Tobacco seriously damages health" and other inscriptions like these. They claim that when it is introduced in the market inscription in Albanian, the customer is the impression that the package is produced only for Albania. Production of cigarette factories in other countries is the same quality for all countries, companies say. Only cardboard printed in Albanian, so therefore the quality is the same.

Consumer mentality has to do with the selection of a product without stamp. Starting from children to sell roads, premises or waiters and other trading items, the opportunity to buy a pack of two choices conditioned, with or without stamp, creating the impression that the product is not original stamp and stamp it with is false. The fact that the extent of such smuggling have been in 2000 does not mean that it is just a matter of control and marketing, but is also a matter of mentality of the market, where consumers prefer to choose the product of uncontrolled ultimately may be very old or fake. A product that can be produced in plants authorized, may have circulated through commercial channels for a very long time getting old.

This product may have 5 or 6 years. So, perception and mindset is very important.

About 40 percent of the cigarettes sold in Albania in the years 200 enter the market through smuggling. Scandalous figures emerged in a study conducted by several universities recognized experts, under the Center for Tobacco Research and Monitoring (England), with funding billionaire "Microsoft" Bill Gates. The higher figure refers to some other countries with emerging economies, such as Bolivia, Uzbekistan and Bosnia and Herzegovina. The highest level of smuggling results have state of Georgia, with about 50 percent. Another concern for researchers, in addition to declining revenue from tax evasion is linked to the health of consumers. According to the study, smoking introduced in the market through smuggling is poor quality and cheap cost, causing death every year about 132 thousand people. Foundation funded by Bill Gates does not provide the trade of cigarettes in Albania, but notes that the bulk of their entering smuggling are not of good quality.

Some time ago, "English" published the latest figures on the level of clearance of cigarettes at customs for the period January-April 2011. Official data from the Directorate General of Customs show a collection at up to 12.5 million dollars, for the period January-April 2011. In quantity, customs clearance reports a level about 954 tons, about 200 tons less than the first four months of 2010. As market value, turnover tobacco imports about 25 million dollars, with half going to taxes, as a result of increased excise taxes in 2009.

Another project funded by the Americans, it turns out that 4000 people were asked in rural and urban areas of different ages, which indicate that tobacco consumption is higher than what is stated, as about 27 percent of smuggled tobacco in country avoiding all fiscal obligations and increased risk for Albanians. Every year in Bangladesh 3800 premature deaths occur from tobacco consumption.

\section{Conclusions}

\section{The case study conclusion}

- The use of $\mathrm{N} 40$ - N90 kg/ha nitrogen dose in the background of P60K60 kg/ha, increases the tobacco productivity up to 19.4 , obtaining an augmentation of 5.3 higher than the background.

- The use of 40 up to $90 \mathrm{~kg} / \mathrm{ha}$ active matter phpsphate in the background of N40P60 kg/ha interfaces of $\mathrm{N} 40 \mathrm{P} 60 \mathrm{~kg} / \mathrm{ha}$ the use of potassium dose of $40-90 \mathrm{~kg} / \mathrm{ha}$ active matter increases the productivity 17.1 .

- The use of $40-90 \mathrm{~kg} / \mathrm{ha}$ active matter potassium dose in the background of N40P60 kg/ha interfaces the productivity up to 18.5 ,obtaining an augmentation of 8.7 higher then the control sample.

- The use of potassium fertilizers in nitrogen- potassium background, improves the tobacco quality and the other indicators such as burn, aromatic herband its pleasantness.

In Albania in 2013 for the tobacco market consists of distributors world-famous parent companies. Who have divided between them the domestic market? Each of these companies has brought to Albania more than two types of marks, with the result that consumers find different flavour cigarettes.

With a tough fight to claim as many smokers among Albanians market, companies use various forms of marketing. Now coming back to the tradition of offering packages in public places, where in some cases they are even free.

Referring to data excise stamps from the Directorate General of Taxation Currently, half of the cigarette market is divided between two large companies, while the rest of the market belongs 4 small companies. But according to the amount of excise tax paid by distributors of cigarettes, in 2012, were circulated over 15 billion All, by selling different brands of cigarettes. 
Based on the important results of the case study and the results of the Albanian market research we find very important economic indicators that suggests us that we should produce and manufacture this plant in Albania.

\section{References}

INSTAT 2013. Institute of Statistics of Albania.

MBUMK 2012. Ministry of Agriculture Food and Consumer Protection.

METE 2011. Ministry of Economy Trade and Energy.

HULK, Uncategorised January 5, 2013.

Reka Fetah: The effect of tobacco fertilization; B.SH.B.No.2, 1986 p.25-30: Tirana ,Albania.

Dauti Myrteza; The cultivation of tobacco

Dabulla Aqif \& Kadiu Peter : Agrochemistry 1989.

Kadiu Peter; Mineral fertilization of big - level tobacco ;B.SH.B.No.1,1991; p.71; Tirana,Albania.

Vangjeli Andrea \& Ohri Edibe; Agrochemistry 1980.

Tabac No. 1; $1982 \mathrm{~m}$ p.53.

Cartell F.\& Devoti P.; Agricoltura ricerca 1993,p.43. 